\title{
Temperatures and Cold Damage to Small Fruit Crops Across the Eastern United States Associated with the April 2007 Freeze
}

\author{
Michele Renee Warmund ${ }^{\mathbf{1 , 4}}$ \\ Division of Plant Sciences, Department of Horticulture, University of Missouri, \\ 1-31 Agriculture Building, Columbia, MO 65211-7140 \\ Patrick Guinan ${ }^{2}$ \\ Missouri Climate Center, Commercial Agriculture Program, \\ University of Missouri, Columbia, MO 65211-7140 \\ Gina Fernandez $z^{3}$ \\ Department of Horticultural Science, North Carolina State University, Raleigh, NC 27695-7609 \\ Additional index words. Fragraria $\times$ ananassa, Rubus, Vaccinium, Vitis, crop injury, weather
}

\begin{abstract}
An unprecedented freeze occurred between 4 and 10 Apr. 2007, causing extensive crop loss across a large area of the United States. This event occurred late in the spring and temperatures were unusually low for an extended period. Lowtemperature injury on small fruit plants was reported in 21 states. Missouri and Arkansas experienced the highest estimated percentages of crop loss of grape (Vitis spp.), strawberry (Fragraria $\times$ ananassa Duch.), blueberry (Vaccinium spp.), and blackberry (Rubus subgenus Rubus Watson). Kentucky and Tennessee also reported high percentages of small fruit crop loss. Temperatures preceding the freeze event in the affected region were unusually warm and many of the crops were at a more advanced stage of growth than they would have been under more usual conditions. Although frost/freeze warnings were issued, the terminology used by different weather forecasters was inconsistent. Growers used various cold protection methods, but these were generally ineffective because of the stage of plant development and/or the advective nature of the freeze. Actual grape and blueberry crop losses may not be known for several years because of secondary injury to plant tissues from various pathogens.
\end{abstract}

The Easter freeze of 2007 occurred during 4 to $10 \mathrm{Apr}$. across a large region of the United States, including much of the central plains, midwest, and into the southeast (Fig. 1). The cold event experienced across much of the region was an advective type of freeze, which was followed by radiative freeze conditions at some locations. Advective freezes are characterized by the movement of a largescale cold air mass into a region with freezing temperatures and a relatively low dew point (Biel, 1961). The cold air layer can range from 152 to $1524 \mathrm{~m}$ aboveground, and wind speeds are usually greater than $2.2 \mathrm{~m} \cdot \mathrm{s}^{-1}$. Temperature inversions do not develop under advective conditions. Because of the size of the air mass during the Apr. 2007 event, cold protection methods were of limited effectiveness. This low-temperature episode significantly affected many of the fruit, nursery, and agronomic crops, causing major economic losses. The North Carolina Department of Agriculture and Consumer Services (2007) estimated that the loss for agricultural crops after the freeze was $\$ 112$ million with fruit crop losses of $\$ 86$ million (D. Hamrick, personal communication). In Missouri,

Received for publication 4 Dec. 2007. Accepted for publication 25 Jan. 2008.

Contribution from the Missouri Agricultural Station project 322.

${ }^{1}$ Professor and State Fruit Extension Specialist.

${ }^{2}$ Extension Assistant Professor and Missouri State Climatologist.

${ }^{3}$ Associate Professor and Extension Specialist.

${ }^{4}$ To whom reprint requests should be addressed; e-mailwarmundm@missouri.edu which has a relatively small commercial fruit industry, the economic value of damaged fruit crops was over \$23 million (M. Warmund, unpublished data). In Kentucky, fruit crop losses were $\$ 15.8$ million and grape and blueberry crop losses were $\$ 3.8$ million in Illinois (National Oceanic and Atmospheric Administration, 2008). The cold wave occurred over an extended period when many of the small fruit crops were at an advanced stage of growth, making it a particularly devastating freeze.

Several factors contributed to the widespread damage to crops. The month of March was particularly warm across the northern plains, the Mississippi Valley, and the south- east. A dominant ridge of high pressure across the lower 48 states caused average monthly temperatures in Mar. 2007 to exceed average temperatures by greater than $3.3{ }^{\circ} \mathrm{C}$ across the affected region (National Climatic Data Center, 2007; U.S. Department of Agriculture, 2007). Ten states had one of the five warmest months of March ever recorded (National Oceanic and Atmospheric Administration, in press). In contrast, cold air across most of Alaska made it the third coldest March on record for the state. In early Apr. 2007, this cold arctic air moved southward into the central and eastern United States. Temperatures dropped below $0{ }^{\circ} \mathrm{C}$ during the night with many hours of freezing 
temperatures for several successive days (Table 1) (National Climatic Data Center, 2007). As many as five nights of cold temperatures with sustained desiccating winds resulted in major agricultural losses (National Oceanic and Atmospheric Administration, 2008). Of the 35,000 daily minimum temperatures recorded in the contiguous United States, 1237 daily minimum temperature records were broken and 321 records were tied during 4 to 10 Apr. 2007. In Arkansas, Kansas, Oklahoma, Tennessee, Mississippi, and Texas, the statewide average temperatures were actually colder in April

During the cold episode, the National Weather Service issued various types of warnings for the affected region. Each state is divided into forecast zones, often by county. In states that have fairly small counties and uniform topography, there is only one forecast zone per county. In states that have large county boundaries, significant elevation change, or coastal influence, counties may be subdivided into multiple forecast zones. However, there are many microclimates within a forecast zone. In addition, terms used by the National Weather Service for issuing warnings vary by state and in their definitions. For example, in Missouri, a frost advisory is issued by the National Weather Service when temperatures are forecasted between 0 and $2.8^{\circ} \mathrm{C}$ with strong radiational cooling (A. Foster, personal communication). A freeze warning is issued when temperatures are expected below $0{ }^{\circ} \mathrm{C}$ for $3 \mathrm{~h}$ or longer or when temperatures are forecasted $-2.2{ }^{\circ} \mathrm{C}$ or lower for any period of time. However, in North Carolina, warnings for forecast regions may be categorized as frost, frost/freeze, or freeze, depending on air temperature ( $1.5 \mathrm{~m}$ above the ground) and wind speed. A frost warning is issued by the National Weather Service when the forecasted air temperature is above $0{ }^{\circ} \mathrm{C}$ and the wind speed is below $4.5 \mathrm{~m} \cdot \mathrm{s}^{-1}$. Frost/freeze than in March.

warnings are given when the temperatures below $0{ }^{\circ} \mathrm{C}$ and wind speeds below $4.5 \mathrm{~m} \cdot \mathrm{s}^{-1}$ are predicted. In contrast, a freeze warning means that temperatures below $0{ }^{\circ} \mathrm{C}$ and wind speeds above $4.5 \mathrm{~m} \cdot \mathrm{s}^{-1}$ are forecasted. Although these terms describe climatic conditions, they do not reflect whether ice nucleation, freezing, and tissue damage will actually occur within the plant. "Critical temperatures" for injury at a specific stage of such crops as grapes, blueberries, and strawberries have been published on various web sites (Michigan State University Extension, 2004, 2005, 2006; Ohio State University, 2002). However, these "critical temperatures" provided only an estimate of the potential crop injury. Because cultivars, plant age, stage of plant development, tissue moisture content, presence of ice nucleationactive bacteria, and climatic factors varied at each location, it was difficult to predict crop survival. When a frost warning is issued, it is likely that a crop can be protected by heating, the use of irrigation, insulating materials (rowcovers, foam, mulch, and so on), or other cultural practices (Rieger, 1989). However, when a frost/freeze warning is issued and temperatures fall below $-4.4{ }^{\circ} \mathrm{C}$ at postbloom, it is much more difficult to avoid crop injury.

Although temperatures at which crop injury occurs have been published on strawberries, blueberries, and grapes (Michigan State University Extension, 2004, 2005, 2006; Ohio State University, 2002), little is known about the survival of blackberries at growth stages at budbreak or later. Research on the supercooling of floral primordia within dormant blackberry buds has been published (Warmund and George, 1990; Warmund et al., 1988, 1992), but low-temperature injury on shoots and floral buds after growth has begun has not been observed or studied before the 2007 cold event to our knowledge.

To provide summaries of crop injury across the region affected by the April freeze,

Table 1. Minimum temperatures, number of hours below various temperatures, and wind speeds recorded at several locations ${ }^{\mathrm{z}, \mathrm{y}}$

\begin{tabular}{|c|c|c|c|c|c|c|c|}
\hline \multirow[b]{2}{*}{ Site } & \multicolumn{5}{|c|}{ No. of hours below each air temp $\left({ }^{\circ} \mathrm{C}\right)$} & \multirow{2}{*}{$\begin{array}{c}\text { Maximum } \\
\text { 10-s wind } \\
\text { speed }\left(\mathrm{m} \cdot \mathrm{s}^{-1}\right)\end{array}$} & \multirow{2}{*}{$\begin{array}{c}\text { Avg. } \\
\text { wind speed } \\
\left(\mathrm{m} \cdot \mathrm{s}^{-1}\right)\end{array}$} \\
\hline & 0 or less & $\leq-2.2$ & $\leq-4.4$ & $\leq-6.7$ & $\leq-8.9$ & & \\
\hline Gadsden, AL & 19 & 11 & 0 & 0 & 0 & 6.7 & 2.2 \\
\hline Selma, AL & 1 & 0 & 0 & 0 & 0 & 0.9 & 0 \\
\hline Batesville, AR & 21 & 17 & 7 & 2 & 0 & 1.8 & 0.9 \\
\hline Watkinsville, GA & 15 & 2 & 0 & 0 & 0 & 3.6 & 1.3 \\
\hline Newton, GA & 3 & 0 & 0 & 0 & 0 & 0.4 & 0 \\
\hline Manhattan, KS & 61 & 28 & 16 & 9 & 2 & 7.2 & 3.1 \\
\hline Bowling Green, KY & 47 & 23 & 9 & 0 & 0 & 3.1 & 0.4 \\
\hline Monroe, LA & 2 & 0 & 0 & 0 & 0 & 0.4 & 0 \\
\hline Chillicothe, MO & 82 & 54 & 21 & 5 & 0 & 9.8 & 4.0 \\
\hline Newton, MS & 2 & 0 & 0 & 0 & 0 & 2.2 & 1.8 \\
\hline Asheville, NC & 47 & 27 & 9 & 0 & 0 & 5.8 & 1.3 \\
\hline Durham, NC & 16 & 3 & 0 & 0 & 0 & 5.8 & 1.8 \\
\hline Stillwater, OK & 19 & 8 & 0 & 0 & 0 & 4.9 & 1.8 \\
\hline Blackville, SC & 9 & 3 & 0 & 0 & 0 & 0.9 & 0.4 \\
\hline McClellanville, SC & 2 & 0 & 0 & 0 & 0 & 1.3 & 0 \\
\hline Crossville, TN & 70 & 45 & 16 & 7 & 3 & 6.7 & 1.8 \\
\hline Charlottesville, VA & 37 & 11 & 0 & 0 & 0 & 5.8 & 1.3 \\
\hline
\end{tabular}

${ }^{\mathrm{z}}$ Wind data are for only the hours during which the temperatures were less than $0{ }^{\circ} \mathrm{C}$ and were measured at $1.5 \mathrm{~m}$ aboveground level.

${ }^{\mathrm{y}}$ Data from the National Climatic Data Center (National Oceanic and Atmospheric Administration, 2008). researchers, extension specialists, and producers were contacted in 21 states (Table 2). Fruit crops in many northern states were still dormant, and thus, there was little damage from the April cold event. However, Nebraska, Kansas, Missouri, Arkansas, Illinois, Kentucky, Tennessee, Indiana, Ohio, Georgia, North and South Carolina, Virginia, and West Virginia had significant losses of small fruit crops. Partially affected regions included northeastern Oklahoma, northern Louisiana, Mississippi, Alabama, and Florida and southern Iowa and Michigan.

Estimates of loss for grape, strawberry, blueberry, and blackberry crops were obtained. Early reports from cooperators indicated that black (Rubus occidentalis L.) and red (Rubus ideaus L.) raspberry plants were not injured in the states affected by the April freeze event. Thus, data were not collected for these crops.

\section{GRAPE CROP LOSS}

The largest grape crop losses were estimated in Missouri, Arkansas, and Tennessee (Fig. 2). Those states reported vine damage as well as crop loss. Crown gall, in response to Agrobacterium tumefaciens [(Smith \& Townsend) Conn] infection, was anticipated where trunks were damaged. In southeastern Nebraska, the greatest crop losses were on grapevines of cultivars such as 'Marechal Foch', 'Leon Millot', 'De Chaunac' [FrenchAmerican hybrids (Vitis vinifera L. $\times$ Vitis labrusca L.)] 'Delaware' (American hybrid), and 'La Crosse' [neo-American hybrid (a 20 th and 21 st century hybrid produced in

Table 2. Cooperators who provided estimates of small fruit crop losses in states affected by the Apr. 2007 freeze event ${ }^{z}$.

\begin{tabular}{|c|c|}
\hline State & Cooperator \\
\hline Arkansas & John Clark \\
\hline Alabama & Elina Coneva \\
\hline Florida & Robert Hochmuth \\
\hline Georgia & $\begin{array}{l}\text { Phil Brannen, } \\
\text { Gerard Krewer }\end{array}$ \\
\hline Illinois & $\begin{array}{c}\text { Mosbah Kushad, } \\
\text { Bob Skirvin }\end{array}$ \\
\hline Indiana & Bruce Bordelon \\
\hline Iowa & Paul Domoto \\
\hline Kansas & Ted Carey, Rex Rees \\
\hline Kentucky & Doug Archbold \\
\hline Louisiana & John Pyzner \\
\hline Michigan & Mark Longstroth \\
\hline Mississippi & $\begin{array}{l}\text { John Braswell, } \\
\text { Steve Stringer }\end{array}$ \\
\hline Missouri & $\begin{array}{l}\text { Keith Streigler, } \\
\text { Michele Warmund }\end{array}$ \\
\hline Nebraska & Paul Read \\
\hline North Carolina & $\begin{array}{l}\text { Bill Cline, Gina Fernandez, } \\
\text { Barclay Poling, } \\
\text { Sara Spayd }\end{array}$ \\
\hline Ohio & $\begin{array}{c}\text { Shawn Wright, } \\
\text { Imed Dami }\end{array}$ \\
\hline Oklahoma & Eric Stafne \\
\hline South Carolina & Walker Miller \\
\hline Tennessee & David Lockwood \\
\hline Virginia & Jeremy Pattison \\
\hline West Virginia & Lewis Jett \\
\hline
\end{tabular}

HortScience Vol. 43(6) October 2008 

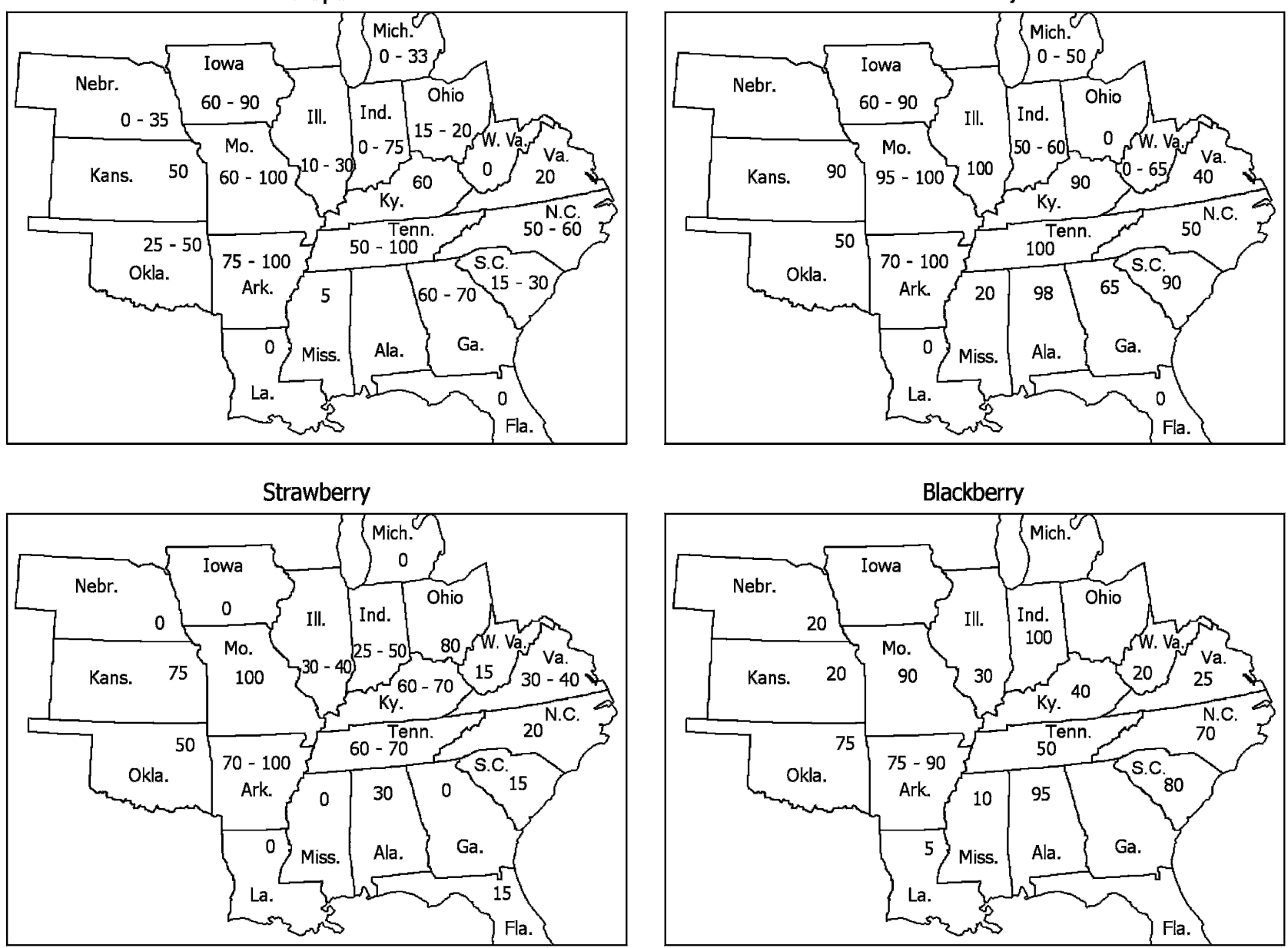

Fig. 2. Percent loss of grape, strawberry, blueberry, and blackberry crops estimated by cooperators in states affected by the 4 to 10 Apr. 2007 freeze event.

North America involving North American Vitis species and $V$. vinifera) ] that had growth from primary buds at the time of the freeze (P.E. Read, personal communication). 'Edelweiss', 'Marquette', and 'St. Croix' (neo-American hybrids) had swollen buds at the time of the cold wave and sustained less damage. Less damage was incurred on latergrowing cultivars such as 'Seyval blanc', 'Chambourcin' (both cultivars French-American hybrids), 'La Crescent', 'Esprit' (both neo-American hybrids), and 'Norton' (Vitis aestivalis Michx.). Damage was absent on 'Prairie Star', Frontenac', and 'Frontenac Gris' (neo-American hybrids). Since the freeze, 'La Crosse' vines set nearly a full crop, and 'St. Croix' and 'Marechal Foch' vines had a $50 \%$ crop produced from secondary buds. In Kansas, there was $50 \%$ grape loss and in northeastern Oklahoma, $25 \%$ to $50 \%$ loss.

In Missouri, many of the wine-grape cultivars had $95 \%$ to $100 \%$ primary bud injury (Table 3). In contrast, 'Norton' exhibited only $70 \%$ primary bud injury and 'Vignoles' (French-American hybrid) had $85 \%$ primary bud loss. For cultivars that were evaluated, secondary bud injury was greatest for the French-American hybrid, 'Chardondel' $(75 \%)$. 'Seyval blanc' exhibited greater than $50 \%$ secondary bud injury, whereas
'Vidal blanc'(French-American hybrid), 'Chambourcin', and 'St. Vincent' (neoAmerican hybrid) had $50 \%$ or less secondary bud loss. 'Frontenac' exhibited 10\% secondary bud kill. Despite these differences in percent bud injury, 'Chambourcin', 'Chardonel', and 'Vidal blanc' had $40 \%$ or less crop loss at harvest (Allen, 2007).

At the Iowa State University Armstrong Research Demonstration Farm, Lewis, IA, primary bud injury was recorded before the cold event on 20 March and after the freeze on 12 Apr. (Table 4) (P.A. Domoto, unpublished data). 'Edelweiss', 'Seyval blanc', 'Marechal Foch', and 'St. Croix' vines had the greatest primary bud injury $(90 \%$ or greater) in April. 'Vanessa', 'Marquis', 'Jupiter', 'Mars', 'Reliance' (American hybrid cultivars), and 'Traminette' (neoAmerican hybrid) had intermediate damage, whereas 'La Crosse', 'Vignoles', 'Norton', and 'Frontenac' had $35 \%$ or less primary bud loss on 12 Apr.

In northern Indiana, many of the grape cultivars were still dormant during the April freeze or they were just beginning to swell (B.P. Bordelon, personal communication). Thus, little crop loss was noted. However, in central and southern Indiana, many of the grapevines had buds with 2 - to 8 -cm growth. Although many of the primary buds were
Table 3. Percent primary and secondary bud injury of various grape cultivars in Missouri after the 4 to 10 Apr. 2007 freeze $^{z}$.

\begin{tabular}{lccc}
\hline & $\begin{array}{c}\text { Type } \\
\text { of } \\
\text { hybrid }\end{array}$ & $\begin{array}{c}\text { Primary } \\
\text { bud } \\
\text { injury } \\
(\%)\end{array}$ & $\begin{array}{c}\text { Secondary } \\
\text { bud } \\
\text { injury } \\
(\%)\end{array}$ \\
Cultivar & AH & 100 & $-{ }^{\mathrm{x}}$ \\
Catawba & AH & 100 & - \\
Chamga White & FA & 95 & $25-50$ \\
Chardonel & FA & 100 & 75 \\
Concord & AH & 100 & \\
Norton & - w & 70 & - \\
Seyval blanc & FA & 100 & $>50$ \\
St. Vincent & NA & 95 & $25-50$ \\
Vidal blanc & FA & 95 & 50 \\
Vignoles & FA & 95 & - \\
Vivant & AH & 100 & - \\
Rougeon & FA & 95 & - \\
Traminette & NA & 95 & - \\
Frontenac & NA & 95 & 10
\end{tabular}

${ }^{\mathrm{z}}$ Data from Allen (2007).

${ }^{y} \mathrm{AH}=$ American hybrid, FA = French-American hybrid, NA = neo-American hybrid. An NA hybrid is a 20th and 21st century hybrid produced in North America involving North American Vitis species and $V$. vinifera. NA hybrids are distinguished from older 18th and 19th century North American hybrids in that they usually involve North American species other than V. labrusca (Jim Luby, personal communication).

${ }^{\mathrm{x}}$ No data recorded.

w'Norton' (Vitis aestivalis). 
Table 4. Percent primary bud injury of various grape cultivars at the Iowa State University Armstrong Research Demonstration Farm, Lewis, IA, before (20 Mar.) and after (12 Apr.) the 2007 cold weather event ${ }^{2}$.

\begin{tabular}{lccc}
\hline Cultivar & $\begin{array}{l}\text { Type of } \\
\text { hybrid }\end{array}$ & 20 Mar. & 12 Apr. \\
\hline Edelweiss & NA & 6 & 97 \\
Seyval blanc & FA & 42 & 94 \\
Marechal Foch & FA & 9 & 93 \\
St. Croix & NA & 1 & 90 \\
Vanessa & AH & 44 & 83 \\
Marquis & AH & 47 & 80 \\
Jupiter & AH & 39 & 78 \\
Mars & AH & 17 & 70 \\
Reliance & AH & 36 & 61 \\
Traminette & AH & 37 & 61 \\
La Crosse & NA & 8 & 35 \\
Vignoles & FA & 22 & 31 \\
Norton & $-{ }^{x}$ & 9 & 31 \\
Frontenac & NA & 0 & 22 \\
\hline
\end{tabular}

zTen distal buds on two canes were examined from each of nine grapevines per cultivar. Vines were trained to a high bilateral cordon system with the high wire at $1.8 \mathrm{~m}$ except for 'Seyval blanc', 'La Crosse', 'Vignole', and 'Traminette', which were trained to a bilateral low cordon system with vertical shoot positioning from a wire at $1.1 \mathrm{~m}$. Data provided by Paul A. Domoto.

${ }^{\mathrm{y}} \mathrm{NA}=$ neo-American hybrid, $\mathrm{FA}=$ FrenchAmerican hybrid, $\mathrm{AH}=$ American hybrid. An NA hybrid is a 20th and 21st century hybrid produced in North America involving North American Vitis species and $V$. vinifera. NA hybrids are distinguished from older 18th and 19th century North American hybrids in that they usually involve North American species other than $V$. labrusca (Jim Luby, personal communication).

'Norton' (Vitis aestivalis).

killed by the cold April temperatures, many French-American hybrid cultivars produced fruit from secondary buds, and only $\approx 50 \%$ of the crop was lost. However, as much as $75 \%$ of the crop was lost for Vitis labrusca cultivars. In Ohio, $V$. vinifera cultivars were still dormant, but bud injury on $V$. labrusca cultivars was observed. No crop loss occurred in West Virginia, but $20 \%$ loss was estimated in Virginia.

In Georgia, 2-year-old 'Chardonnay' $(\mathrm{Vi}$ tis vinifera L.) and 'Suwannee' (Vitis $\times$ sp.) scions were killed back to the graft union and disease infection from secondary pathogens was expected on many grapevines. In North Carolina, some muscadine grape (Vitis rotundifolia Michx.) vineyards were severely injured by the freeze (W.O. Cline, personal communication). Damaged cordons and trunks were removed in many of these vineyards. As a result of the low-temperature injury, fungal (Botryosphaeria spp.) and bacterial (Agrobacterium tumefaciens) infections were anticipated. Little crop loss $(5 \%)$ was reported in Mississippi, and no crop injury was reported in northern Louisiana and Florida.

\section{STRAWBERRY CROP LOSS}

In Nebraska, Iowa, and Michigan, dormant strawberry plants were still under floating rowcover or mulch and did not have crop loss from the April freeze event. In contrast, all strawberries grown in matted rows or in unheated high tunnels in Missouri were lost as a result of the freeze event (Fig. 2). Significant crop losses (50\% or greater) were also reported in northeastern Kansas and Oklahoma, Arkansas, Kentucky, and Tennessee. In southern Illinois, $30 \%$ to $40 \%$ crop loss was estimated, and a wide range of loss was reported for southern Indiana. In Ohio, $80 \%$ crop loss was observed on plasticulture systems, whereas no damage was reported for strawberries grown in the matted row system (S.R. Wright, personal communication). In the western Piedmont area of North Carolina, crop losses exceeded $50 \%$ as a result of the low temperatures and winds in excess of 4.5 $\mathrm{m} \cdot \mathrm{s}^{-1}$ (Poling, 2007). In the eastern part of North Carolina, a radiational freeze occurred in the early hours of $8 \mathrm{Apr}$. and growers saved $90 \%$ of the open strawberry blossoms using sprinkler irrigation. In the central Piedmont, sandhill, and coastal plain of North Carolina, where lightweight $\left(33.8 \mathrm{~g} \cdot \mathrm{m}^{-2}\right)$ rowcovers were used, crop injury was reported below $-4.4{ }^{\circ} \mathrm{C}$. In contrast, less crop injury occurred when lightweight rowcovers were used in combination with sprinkler irrigation or heavier weight $\left(50.6 \mathrm{~g} \cdot \mathrm{m}^{-2}\right)$ rowcovers were used. In northern Alabama, 30\% strawberry crop loss was estimated, whereas $15 \%$ loss was reported for South Carolina and northern Florida. No strawberry injury was reported for Louisiana, Mississippi, or Georgia.

\section{BLUEBERRY CROP LOSS}

In southern Iowa, Kansas, Missouri, Arkansas, Illinois, Kentucky, and Tennessee, as much as $90 \%$ to $100 \%$ of the northern highbush blueberry (Vaccinium corymbosum L.) crop was lost from the freeze event (Fig. 2). Crop loss was not reported for Nebraska because few blueberries are grown there. In Indiana, $50 \%$ to $60 \%$ of the highbush blueberry crop was eliminated by cold April temperatures. As much as $50 \%$ of the highbush blueberry crop was lost in southeast Michigan, whereas no damage was reported in the western part of the state, where temperatures were moderated by Lake Michigan. In Ohio, fruit survived the cold event but was marred by frost rings. In Oklahoma, Virginia, and North Carolina, $40 \%$ to $50 \%$ crop loss was estimated. At Castle Hayne, NC, earlyripening southern highbush (Vaccinium corymbosum L. hybrids) cultivars Star and O'Neal had green fruit, whereas half of the blossoms of the northern highbush cultivar Croatan were open on 5 Apr. By 8 Apr., the temperature at the Castle Hayne site had dropped to $-6.1{ }^{\circ} \mathrm{C}$. At White Lake, minimum daily temperatures of $-2.7,1.4,-7.1$, -3.1 , and $-3.6{ }^{\circ} \mathrm{C}$ were recorded during the cold episode. Because this was such an atypical cold event, many growers used overhead irrigation for four consecutive nights, but some lacked sufficient water to apply it this many nights. Although temperatures recorded at White Lake were too extreme to protect the crop in this manner, growers at warmer locations were able to protect their blueberry crop with irrigation. During the prolonged cold episode, many of the flowers unaffected by the low temperatures were not pollinated by bees and subsequently dropped.

In North Carolina, two diseases were exacerbated by the freeze event. Symptoms of flower blight and twig dieback caused by gray mold (Botrytis cinerea Pers.:Fr.) were exhibited 7 to $10 \mathrm{~d}$ after the freeze (W.O. Cline, personal communication). Gray mold was most severe on cultivars that were in the early stage of bloom. Symptoms of blueberry stem dieback [Botryosphaeria dothidea (Moug.:Fr.) Ces \& De Not] infection were also observed $\approx 1$ month after the freeze event in North Carolina. To limit this disease, producers removed infected wood by mowing the plants at 0.9 to $1.2 \mathrm{~m}$ above the soil surface when they had complete crop loss. Those who had partial crop loss selectively removed infected canes from plants during the growing season or mowed infected plants after harvest.

Major blueberry crop loss occurred in South Carolina $(90 \%)$ and in northern Alabama (98\%), where temperatures preceding the freeze ranged from -2 to $0{ }^{\circ} \mathrm{C}$. No damage on blueberry plants was observed in northern Florida or Louisiana, but $20 \%$ crop loss was estimated for northern Mississippi.

\section{BLACKBERRY CROP LOSS}

In northeastern Oklahoma, Arkansas, Missouri, Indiana, North Carolina, South Carolina, and northern Alabama, $70 \%$ or greater of the blackberry crop was eliminated by the April freeze (Fig. 2). In Ohio, the crop was injured previously by low temperatures during the winter. Few blackberries are commercially produced in Nebraska, Iowa, Georgia, and Florida, so losses were not reported. In Bailey, NC, where the minimum temperature recorded on $8 \mathrm{Apr}$. was $-5.6^{\circ} \mathrm{C}$, percent live floral buds on five nonbranching canes (i.e., no tipping during the previous season) of four blackberry cultivars was recorded on 10 Apr. 2007. Four-year-old plants of 'Apache', Arapaho', 'Navaho', and 'Ouachita' were trained to a shift trellis with the canes in a horizontal position during the freeze event. Budbreak had occurred within the previous week and flower buds had recently emerged on the new lateral growth. All visible buds of 'Apache', 'Arapaho', and 'Ouachita' exhibited oxidative browning. However, only $19 \%$ of the visible 'Navaho' buds appeared injured. On 1 May 2007 , at the same location, the number of injured and noninjured flowers per lateral cane was recorded again on the same cultivars. Data were obtained from one cane per plant of six replications of each cultivar. The percentages of dead flowers (dead flowers/ total flowers) for 'Apache', 'Arapaho', 'Navaho', and 'Ouachita' were 6, 47, 12, and 58, respectively. Visual inspection of the plants indicated that growth from the 'Apache', 'Arapaho', and 'Ouachita' buds 
had likely developed from secondary buds (Fernandez, 2007).

In Missouri, the freeze came after the third warmest 21 Mar. through 3 Apr. period on record and was followed by the coldest 4 Apr. to 9 Apr. period on record (since 1898) (Guinan, 2007). On 7 Apr. 2007, the temperature at the Horticulture and Agroforestry Research Center at New Franklin, MO, dropped to $-7.3{ }^{\circ} \mathrm{C}$. From 4 to 9 Apr., temperatures were below freezing for $67 \mathrm{~h}$. At the time of the cold event, blackberry shoots on 8 -year-old nontrellised plants were as long as $15 \mathrm{~cm}$. Immediately after the cold event, shoots were flaccid and leaves appeared wilted. By the next week, all new growth from buds on the floricanes was necrotic. However, by 9 May, new foliage, fruit, and flowers were visible on floricanes of several cultivars, but not 'Kiowa'. Although flowers and fruit were not observed on 'Kiowa' floricanes, new primocane growth was visible. The number of flower or fruit clusters per plant was recorded on 9 May from three plant replicates of five replications of each cultivar. 'Darrow' plants averaged 109 flower or fruit clusters per plant, whereas 'Shawnee', 'Arapaho', 'Apache', and 'Chickasaw' had $14,13,13$, and 11 clusters per plant, respectively. 'Navaho' had five flower or fruit clusters per plant and 'Choctaw' averaged three clusters per plant. Harvest was delayed by 4 weeks and fruit size was reduced by approximately one-third on 'Arapaho', 'Navaho', and 'Apache' plants. These cultivars typically produce nine fruit per cluster but produced only five fruit per cluster in 2007 (M.R. Warmund, unpublished data). Although comparative data on dates of budbreak have not been reported, the lack of crop on 'Kiowa' was most likely the result of its growth in early spring (J.R. Clark, personal communication). Floral survival on the other blackberry cultivars may be attributed to subsequent or late growth from primary buds after the freeze event. Alternatively, flowers may have developed on growth from surviving secondary buds. In earlier work, Warmund and George (1990) observed as many as three differentiated floral primordia in secondary buds of 'Darrow' and up to seven floral primordial in 'Choctaw' and 'Navaho' in late February. In contrast, 'Shawnee' had only one differentiated floral primordium by late February. In cultivars such as 'Humble', 'Brison', 'Brazos', less than $1 \%$ of the secondary buds had differentiated floral primordia in late February. Thus, differences in the 2007 crop among various cultivars may be attributed to fruit produced from late-emerging primary shoots, varying numbers of secondary buds on cultivars, and/or the number of fruit per secondary bud.

\section{PRESENT AND FUTURE OUTLOOK}

Data presented represent estimates of crop loss by individuals familiar with their states' fruit industries. However, the true consequences of this historic April freeze may not be determined for several years. Disease infection after the freeze, especially on grapevines and blueberry plants, will have long-term effects on production and crop yields. For example, crown gall on grapevines will likely be problematic because few eradicants are available to inhibit all strains of the bacteria once infection has occurred. Thus, grape growers may replant different cultivars or alternative crops where vines incurred severe injury. In the future, research efforts will be focused on postbloom lowtemperature injury, fruiting potential from secondary buds of grapes and blackberry, and protection of fruit crops during advective freezes. A clearer understanding of ice nucleation and propagation in the developed tissues will aid in the development of new and effective protective strategies against lowtemperature injury caused by advective freezes. Lastly, standardization of terms and the criteria for frost and freeze advisories and warnings issued by the National Weather Service within and among states will assist producers in their efforts to eliminate or reduce low-temperature injury in fruit crops.

\section{Literature Cited}

Allen, A. 2007. What we learned from the Easter freeze in Missouri. Proc. Understanding and Preventing Freeze Damage in Vineyards Workshop. p. 95-106.

Biel, E.R. 1961. Microclimate, bioclimatology and notes on comparative dynamic climatology. Amer. Scientist 49:327-357.
Fernandez, G. 2007. Freeze hits North Carolina blackberry growers in 2007. Southern Reg. Small Fruit Consortium. Vol. 7, No. 3, July 2007, p. 2-4. 10 Jan. 2008. <http://www.small fruits.org/Newsletter/SmallFruitNews.htm>.

Guinan, P. 2007. The Easter freeze of 2007-What happened? Proc. Understanding and Preventing Freeze Damage in Vineyards Workshop. p. 712.

Michigan State University Extension. 2004. Critical spring temperatures for tree fruit and small fruit bud stages. 27 June 2007. <http://web1. msue.msu.edu/vanburen/crtmptxt.htm>.

Michigan State University Extension. 2005. Michigan grapes. 27 June 2007. <http://web1 msue.msu.edu/fruit/grpfrost.htm>.

Michigan State University Extension. 2006. Blueberry growth stages. 27 June 2007. <http:// www.blueberries.msu.edu/pdf/growthstages. pdf $>$.

National Climatic Data Center. 2007. Apr. 2007 cold wave. 2 July 2007. <http://www.ncdc. noaa.gov/oa/climate/research/2007/apr/apr-coldevent.php>.

National Oceanic and Atmospheric Administration. 2008. Easter freeze of April 2007: A climatological perspective and assessment of impact and services. Tech. Rpt. 2008-01, Asheville, N.C.

North Carolina Department of Agriculture and Consumer Services. 2007. Agricultural review. 10 Sept. 2007. <http://www.ncagr.com/paffairs/ agreview/articles/2007/5\%2D07freeze.htm>.

Ohio State University. 2002. Fruit ICM news. Vol 6, No. 11. 27 June 2007. <http://ipm.osu.edu/ fruit/02icm11.htm>.

Poling, B.E. 2007. Easter freeze report: Impact on 2007 strawberry crop in North Carolina. Southern Reg. Small Fruit Consortium. Vol. 7, No. 3 , July 2007 , p. 6.10 Jan. 2008. <http://www. smallfruits.org/Newsletter/SmallFruitNews.htm>.

Rieger, M. 1989. Freeze protection for horticultural crops, p. 45-109. In: Janick, J. (ed.). Horticultural reviews. Vol. 11. Timber Press, Portland, OR.

U.S. Department of Agriculture. 2007. Weekly weather and crop bulletin. 94:1-28.

Warmund, M.R. and M.F. George. 1990. Freezing survival and supercooling in primary and secondary buds of Rubus spp. Can. J. Plant Sci. 70:893-904.

Warmund, M.R., M.F. George, and B.G. Cumbie. 1988. Supercooling in 'Darrow' blackberry. J. Amer. Soc. Hort. Sci. 113:418-422.

Warmund, M.R., F. Takeda, and G.A. Davis. 1992. Supercooling and extracellular ice formation in differentiating buds of eastern thornless blackberry. J. Amer. Soc. Hort. Sci. 117:941945. 